InVisible Culture • Issue 31: Black Studies Now and the CounterCurrents of Hazel Carby

\title{
What's Haunting Black Feminism?
}

\author{
Alanna Prince ${ }^{1}$, Alisa V. Prince \\ ${ }^{1}$ Northeastern University
}

Published on: Nov 15, 2020

DOI: $10.47761 / 494 a 02 f 6 . d 5011 d 73$

License: Creative Commons Attribution 4.0 International License (CC-BY 4.0). 


\section{Two Black Feminists Go For A Walk}

On a Wednesday afternoon, we walked down Massachusetts Avenue in Cambridge, our hometown. We saw the center aisle of the street lined with older white people holding signs for Black Lives Matter and cheering each other on. Most cars passing by were honking. The sensation that we felt while passing by this scene is best characterized as when "Happy Birthday" is being sung to you, perhaps by people you don't know very well. It's directed at you but you just sort of wait it out awkwardly, unsure what to do with yourself until it's over. Smile?

Almost through the song and dance, a white woman walking toward us on the sidewalk stopped to share in the BLM hurrah with her peers. But moments after, as she approached us, she swiftly put her head down and ignored our hello. This is not atypical. It is a classic and frequent real life demonstration of the character of many white liberals. Their BLM fanfare is not at all for Black Lives. It is to announce themselves as "good" or virtuous people, and to boost this sense of themselves for their own comfort.

So much has happened, but so little has changed. When we began writing, Breonna Taylor, Ahmaud Arbery, Dominique Fells, and George Floyd were alive. The tidal wave of civil unrest in response to their murders has swayed our thoughts and feelings, and the terms of political and social engagement. When we began writing, we were assessing what haunts Black Feminism. Avery Gordon conceptualizes haunting as a persistent and pestering something for which modes of inquiry and their associated vocabularies cannot account. $\underline{1}$ Our interest stemmed from the difference between that which haunts and that which is tradition. Haunting evokes a given, uncontrollable, continuous force. Tradition is also marked by continuity, but it is a more malleable social convention.

The very process of writing this essay has been haunted by a more obvious kind of haunting. In daily exchanges we reflected on the state of our race, and finally realized that it would be remiss to ignore that haunting is more widely associated with death and ghosts. In our own frenzy to understand what haunts Black Feminism as intellectuals, we nearly bypassed the haunting we live with. What our experiences had already laid out for us perhaps should have been the point of departure: the fact that Black people are always already haunted by Black people who have been murdered by white supremacist violence. It would have been heedless to ignore haunting's association with death in popular culture because this language connects us to Black 
feminism by way of the Black Lives Matter movement, too. BLM was founded by a group of Black women, Alicia Garza, Patrisse Cullors, and Opal Tometi (two of whom identify as queer), in 2013 in response to Trayvon Martin's murderer being acquitted of murder. Answering to Black death was at the very origin of action for Black lives.

Our own practice of mourning finally ignited what should have been obvious to us much earlier about what haunts Black Feminism, what haunts us. The re-realization that our work, or the experience of our work being inextricably tied up with mourning is a fact that haunts this writing. It has shaped and reshaped this work over and over again, with each planned "writing day" that was overcome by sorrow, overcome by more news of death, overcome by the utter need to tend to "real life" unfolding before us, and overcome by the fact that so much has happened, but so little has changed.

In the Ivory Tower, we took Gordon's haunting as an abstract conceptualization and found it immensely valuable for what it describes. But Black feminism is and always has been beset not only with the troubles of the Academy but also the work on the ground of accounting for and fighting to transform Black lives. This essay assesses a multitude of ways in which Black feminism is haunted.

\section{The Impasse at the Intersection}

Hazel V. Carby has described the illusory nature of Black and white women's solidarity. She provides an account that illuminates how (white) feminism positions Black women-our perspectives and experiences and languages-and compresses them to fit within what they have deemed fathomable, which simultaneously includes and excludes Black women from their feminism. She presented the predicament of Black women attending Chicago's Columbian Exposition in 1893, and highlighted:

The fact that six black women eventually addressed the World's Congress was not the result of a practice of sisterhood or evidence of a concern to provide a black political presence but part of a discourse of exoticism that pervaded the fair. Black Americans were included in a highly selective manner as a part of exhibits with other ethnic groups which reinforced conventional racist attitudes of the American imagination. $\underline{2}$

The six black women-Frances Harper, Fannie Barrier Williams, Anna Julia Cooper, Fannie Jackson Coppin, Sarah J. Early, and Hallie Quinn Brown-who spoke as a part of the Congress of Representative Women inhabited a deeply complex position. Ripe with 
contradiction, this position at once included the women as present participants, but excluded in the dominant discourses of white women's and race politics more broadly. $\underline{3}$ This is not unlike the academic who adds a day, perhaps even a week, to their syllabus during which they discuss race with their students, as if race is not ever present and implicated amidst whatever other topics they address. "Next week we're watching Looking for Langston!" they direct at the least white person in the room, awaiting praise. Proudly, they pat themselves on the back, and even boast to us that they are 'woke.'

The experience of Black women at the exposition and our encounter with these BLMers on the streets of Cambridge are both historically and materially distinct. However, considering the two in tandem exposes a particular hauntedness in the nature of Black and white relations. In 1893, white women were more openly reluctant (and even hostile) to welcome Black women speakers. $\underline{4}$ The result was the awkward undervalued presence of Black women's voices. In recent years, some white people are vocal and even ostensibly willing to include race matters in their social justice praxes, but the common result that our encounter illustrates is the failure to put BLM into practice beyond the realm of their lives reserved for "activism." That is, to not only shout "Black Lives Matter!" when it is convenient but to live in such a way that demonstrates that Black lives matter-even without the audience that organized activism and social media provide to affirm one's character.

This marks the first haunting we identify within Black Feminism. The one we initially set out to describe by revisiting some of the concerns that Carby has raised, particularly the question of solidarity, in our contemporary moment. The nature of a haunting ensures that the "it" is difficult to pinpoint, but there is indeed a visceral, persistent, and pestering something, that cannot seem to be assuaged betwixt Black and white women's calls for justice. We posit that this is the reason allyship, sisterhood, and other names for Black and white women's unity have consistently floundered, succeeding as performative and symbolic at best.

Despite the popularity of intersectionality in recent years, it is evident that there is also something getting in the way of our collaborative efforts. This apparent disconnect or, better put, inability to connect exposes an impasse at the intersection of race and gender where Black and white women meet. Afro-pessimist theory, which posits that Black ontology is fundamentally transhistorical and marked by the condition of nonbeing, helps us to understand this immiscibility. As Frank Wilderson 
explains, "[w]hereas Humans exist on some plane of being and thus can become existentially present through some struggle for/of/through recognition, Blacks cannot attain the plane of recognition." $\underline{5}$ We invoke Wilderson's theory to understand the disconnect between Black ontology and contemporary Black feminist discourse. The "plane of recognition" that he proposes identifies a crucial aspect of the haunting we set out to describe. Whereas white women's activism can be described as a struggle for recognition, their partnerships with Black women fall short as they routinely demonstrate that Black women are not, or cannot be, located on the same plane of recognition.

This impasse at the intersection haunts in such a way that erodes the notion of crossracial sisterhood. We identify it not to say that important and beneficial alliances between Black and white women are impossible but to query and to reframe what is possible. Gordon contends that confrontation with hauntings "requires (or produces)" new ways of knowing and making knowledge-perhaps easing the intensity of the haunting. $\underline{6}$ Black feminism conceptualizes racism, sexism, queerphobia, and class oppression as interacting forces that determine social positionalities, the context from which all individual experiences are lived. This line of thought traces back centuries: Sojourner Truth's famous “Ain't I a Woman?” speech of 1827 has reverberated through the past two centuries-with the Combahee River Collective taking this framework up in their influential "Combahee River Collective Statement" (1977), and possibly most famously with Kimberlé Crenshaw's preeminent analytic framework of intersectionality from 1989's “Demarginalizing the Intersection of Race and Sex: A Black Feminist Critique of Antidiscrimination Doctrine, Feminist Theory and Antiracist Politics." However, current Black feminist scholarship has begun to push back against intersectionality, with one critique being the misrepresentation of all intersecting identities as functioning in the same way (in terms of how they manifest) and to the same degree (in terms of how they matter). And another, of the term's cooptation into the discourse of diversity and inclusion in a manner that actually undermines the very purpose of the analytic-to expose and to understand interacting forces of oppression.

Jennifer C. Nash advances that much of Black feminism is now marked by defensiveness, a drive to maintain ownership of intersectionality and use it in such a way that privileges Black women. Carby described the tension felt by Black woman writers wherein while seeking to privilege their experiences, they were confined to a discourse of social conventions about Black womanhood. We identify a connection between this tension and the present day "defensiveness" cited by Nash. And we propose that like the spurious solidarity that Carby interrogated, the current 
"intersectionalities wars" are also symptomatic of the haunting impasse that we set out to understand. We take up the intersectionality wars not to argue for the ownership or release of the analytic, but to consider the implications of this debate and what they might reveal about what haunts Black feminism.

Nash implores Black feminism to release intersectionality. She offers that doing so will create space for scholarship from other identity locations and subsequently push Black feminism forward by dissociating it from Black women's bodies, which "haunt[s] the analytic...even if [she is] not always explicitly named." $\underline{7}$ This fact points to how Black feminism always straddles the border that demarcates academia and the rest. The racial and sexual oppression of Black women has shaped decades of Black feminist theorizing to routinuely note that our freedom, frees us all. Black feminism inherently sets out to help everyone. But its proponents remain aware that white counterparts of everyone have proven themselves willing and ready to use (read: steal) Black Women's knowledge, aesthetics, labor, etc. in order to improve their own conditions and without regard for (or attribution to) Black women who catalyze and enable them.

Nash's discussion of intersectionality, and her critique that Black feminists often express defensiveness, particularly over the right to use the analytic, is revelatory of this tension. She helps us to better understand the nature of the haunting. Should Black feminism exorcise intersectionality, a space must be created and maintained for open and productive conversations about how exactly "letting go" should look. Intersectionality is far too often deployed as a politically correct theoretical cloak by nonBlack feminists who, in practice, navigate the world without concern for the intersections of identities and their implications. In the current state intersectionality is by and large misappropriated and misused beyond recognition. It is used for profit (a number of beauty companies claim they are an intersectional business because they have products that work for everyone-“It's for all skin tones!") or it is used merely as a moniker, or used to describe a type of feminism that allows Black women to have a seat at the table but does not let them speak or be served.

It is in this way that intersectionality is now characterized by the simultaneous inclusion and exclusion of Black women that Carby described. An inarticulable certainly there but so very not there that haunts Black feminist exchanges and collaborations with other groups. Or, Black feminism's place in society. To return to WIlderson, the fact of the impasse begs the question of whether two identity positions operating on different planes of recognition can ever truly intersect. At the alleged intersection where Black and white feminists meet we are socio-politically impuissant, 
too often feigning sisterhood rather than addressing the haunting verity that we are not, and cannot be, "sisters" head on. This haunting was produced and is reproduced by the knowledge that white people's interactions with nonwhite women are often perilous. Black feminism traverses the realms of theory and practice, and thus we experience this first type of haunting not only in the Academy but in our daily lives as well. It unfurls differently in different spaces, with each one revealing different symptoms of the same haunting. We take up the historical presences and absences of Blackness in the visual field to expand the grounds of this haunting and, eventually, return us to our contemporary moment.

\section{A Haunting We Can See}

In 1955, Emmett Till was murdered at the hands of white supremacists in Money, Mississippi. Mamie Elizabeth Till, his mother, made the decision to allow photographers from Jet Magazine to photograph her son's funeral. The resultant photographs depicting Emmett's mutilated body and his loved ones in mourning were published in Jet and The Chicago Defender, creating a spectacle of Black death in the public sphere that intended to draw attention to the violent consequence of racism in the United States.

To understand the weight of the spectacularization of Emmett Till's corpse, it is necessary that the social climate in which it occurred be described briefly. Not unlike today, prior to his murder, early twentieth-century United States media and discourse had already effectively normalized Black death as a part of the public sphere. One hundred and one summers ago, the "Red Summer" of 1919 solidified the normalization of Black death in the everyday visual field so thoroughly that the period is named for the blood of Black people. Black bodies are rendered fungible, and historically, as a result, confrontations with Black death have been met with indifference. $\underline{8}$ However, privately, these deaths were met by Black families much differently than the treatment that was given to them in mainstream discourse.

Black lives have always mattered to Black people. Mamie Till explained, "I wanted the world to see what they did to my baby," as she circulated the image of her mutilated son. Her words countered the notion of the fungibility of the Black body and instead, presented the figure in the image as her son, a young boy, a human being with real familial ties, whose death and its cause, will be (and are/continue to be) recognized by the public. The implication of her statement is an aim to draw the attention of the public to the absurdity and violence of racism. It was a call for political action. 
Asserting her baby's subjecthood reinscribed life to the Black figure photographed. Funeral portraits are typically held privately among mourners close to the deceased. By instrumentalizing funeral photography to make evidence of violence and mourning visible at once, Mamie Till created a jarring juxtaposition between public and private treatment of Black death. In her own production of historical record, Mamie Till repositioned private tradition in the view of the public to illuminate the violent impact of racism as it manifested in Emmett's death. Through this personalized presentation of Black death in a space that normalized and traditionally anonymized it, she effectively mobilized her haunting by denying the boundary between the public and private spheres and thrusting acknowledgement of her son's mutilated figure into the visual field of the public. This gesture marked her refusal to allow her son to fall victim to a second iteration of violence that would have been carried out by the public's tolerance of his mutilating murder as anonymous, insignificant, or most simply, altogether ignored.

"What was hidden was now revealed." Dana Schultz explains the photographs that circulated of Emmett Till's open casket. The 2017 Whitney Biennial featured Schultz's Open Casket, a topographically painted rendition of this spectacle. The display of this work fomented substantial controversy; many called for its removal, and even destruction. $\underline{9}$ As the curators of the Whitney Biennial reiterate, the museum is a place that can function as a platform for political discourse. $\underline{10}$ Such impassioned responses to Schultz's spectacularization of Black death in the art world inspire a call for a historicized examination of the role of these types of displays in order to effectively assess what they can "reveal" to the public.

"I did not know if I could make this painting, ethically or emotionally. I don't know what it is like to be [B]lack in America. But I do know what it is like to be a mother." She said, not seeing that white motherhood and Black motherhood entail entirely different processes and experiences. The Biennial revealed to us that indeed she could overcome ethics and emotions and make this painting. The privileges that enabled her to center herself with regard to Black death is precisely why allyship so often falls short more broadly. This fuels the haunting. The discourse that surrounds Schultz's work as a spectacle of Black death needs to be repositioned beyond the surface level question of censorship and moral opinion, and grounded in an understanding of the nature of the space that the work actually produces. What exactly was hidden and is now revealed by Schultz's piece? 
Mamie Till should have been the last person to circulate such gruesome images. Instead, we have continued to see years of visual evidence of white supremacist violence and imagery of Black death. With the onset of social media this has expanded exponentially; unfiltered and unregulated, we see endless circulation and repetition of these acts. Mamie Till's choice to pursue the publication of images of her deceased son marked the fusing together of her mourning and activism. She felt an impulse that so many of us feel, to document and display white violence in the name of justice for its victims. To extend this lineage to our contemporary moment (keeping in mind the thousands of documented cases of violence in between), the murders of George Floyd, Ahmaud Arbery, and Rayshard Brooks were recorded and then broadcasted to the world. It appears that there is and has been a belief that if we just reveal to the world how violent, racist, and utterly despicable white supremacy is, if we just have evidence of it, morality will kick in, and it can stop. While this may force a sort of reckoning for the unenlightened, we must also ask if it is worth this second order of violence continues to traumatize the very same people whose lives we are attempting to save?

Spectacles of Black death have a history of use as objects that incite discussion surrounding social ideologies and perhaps even stimulate political action. Recently, the public response to videos of the murders of Floyd, Arbery, and Brooks have evinced this fact. The critique of Schultz's version of Till's open casket must assess the function and result of her reanimation of the (already) spectacularized photograph. We reflect on Schultz's painting as a relatively recent example of how ignorance to the import of treatment of Black death is harmful, with hopes that doing so informs our contemporary moment in which similar responses are sprouting up.

The role of social media in contemporary life has been amplified over the past six months, as in-person social interaction has been limited like never before. This summer while quarantined in our homes, whatever and however many offline conceptualization of Self each of us may have held were forcibly merged with our social media avatar. For many, this is wildly jarring. With the concurrent civil uproar and COVID-19, it became clearer than ever that whether or not one is willing to protest in the streets, how one uses their social media platforms announces their politics. And there is no winning in silence. No longer could anyone reserve social media for aesthetic play and memes and not expect to be called out. Midsummer developed a palpable tension that dared anyone, especially nonBlack people who lay claim to any stake in racial justice not to speak out. The pressure turned up. 
Social media is often criticized for forcing people to routinely perform their cyberself and inducing anxieties over likes, comments, and general approval from the public. Right now, the political and social demand for public approval is faced with the fact that Black Lives Matter. To obtain that approval, people are willing to scream it, shout it, and hashtag it. But too many (particularly nonBlack people) seem to not know why. For them, it leaves BLM as just a theory, an ideology at best. The issue is that so-called allies are taking on this rallying cry and failing to live it as praxis. This means conducting themselves as though Black lives matter when there is no audience, no kudos, no direct benefits to their own lives, or even when it means giving something of their own privilege up. It also means reckoning with such privilege and doing the work to dismantle the structures that enable it rather than passively continuing to benefit where possible.

Protesters in response to the murders of Breonna Taylor, Ahmaud Arbery, and George Floyd are screaming, "Black Lives Matter!” throughout the country. We are experiencing an unequivocally unique moment in history. Not because people are rioting about race relations in America-that has been occurring, recurring, and recurring again for centuries-but because white people finally feel watched. $\underline{11}$ This sensation shifts our earlier allegations of the disjuncture between social justice theory and practice; it has generated attempts to suture the two and unearths new consequences of the haunting we have described.

On March 13, 2020, just a little after midnight, a sleeping Breonna Taylor was shot in her own home after police officers knocked down her door without warning. Experts agreed a "no-knock warrant" - which allowed them to raid the house without knocking, but still required them to identify themselves (which Taylor's partner and sixteen neighbors assert did not happen)-was not the appropriate course of action. Radley Balko, a Washington Post columnist and expert on police militarization and civil liberties, makes it clear that the team involved did not clear the necessary hurdles to obtain this type of warrant, and yet Judge Mary Shaw signed off on it. $\underline{12}$ Even more alarming, Taylor was not the subject of the warrant. The warrant was for the arrest of Jamarcus Glover, an associate of Taylor's who had used her address in the past. Records show that Glover was already in custody during the time of the botched search and subsequent murder. The officers involved, Jonathan Mattingly, Brett Hankison, and Myles Cosgrove have not faced any consequences. In the schema of police brutality the wrong type of warrant, the wrong information, and undue process mean little-it is about instilling fear in all Black people by making a violent spectacle, rather than the actual indictment of any individual. 
So little is occurring in the name of justice for Taylor and her family. We find ourselves conflicted: we are glad Breonna's Law is passed in Louisville. $\underline{13}$ But we know that police are just as dangerous, whether or not they knock first. A knock on the door from a police officer (or any encounter with them for that matter) is just as dangerous as them barging into your home. We know this from George Floyd. We know this from Rayshard Brooks. We know this from Sandra Bland. We know this. We know this.

Her murder was not caught on camera, and did not circulate heavily on social media at first, unlike that of Eric Garner, Walter Scott, or Anton Sterling, and so it did not immediately ignite the same large scale protests like we saw in New York, Ferguson, or New Orleans. It was nearly two months later, in the aftermath of the murder of George Floyd of Minneapolis, MN at the hands of Officer Derrick Chauvin, when people began to wonder why attention was not being called to Black women who are almost just as likely to be harmed by police, but do not garner the same ire from protestors. That questioning, done mainly by Black feminists, led to the exposure of Taylor's case, entering her into this national conversation.

Unlike the violent images that bombarded us of the several men that were murdered this spring and summer, we saw very different kinds of images of Taylor, showing her standing giddily in uniform as she passed her EMT exam, taking smiling selfies, and captured in "the golden hour" of the evening where the light creates a sort of glow around her face, angelicizing her in a way that speaks to the good nature she was known to have. \#DefundThePolice developed in June, in response to Floyd's murder, but quickly became associated with the faces of all of those who have been murdered by the police. Seeing these images of Taylor encouraged people to consider abolition, many for the very first time, but they also endeared her to them so much that they felt they had a personal stake in getting her justice through the officer's arrest.

Take the "memeification" of the term "arrest the cops who killed Breonna Taylor." Many people shared this alongside these images of Taylor, without realizing the troubling contradictions inherent to this call. Arresting the cops is not the justice Taylor needs-the cops are already embedded in that very system that allowed her to be murdered with zero immediate consequence. How can anyone simultaneously call for abolition and to arrest those cops? What is more important for justice? The excessive calls for action in either direction expose a major problem: a desire to speak and call for action but no concretized plan. Scrambling to say the right things and make the right appearances, it seems no one has the time to think about what is next. And we wonder if, just like the woman who ignored us on Mass Ave, if people are 
taking this into heart and putting it into practice, or if they are only concerned with their own image. We must interrogate not only how Taylor is represented on social media but also what is done with these representations.

Artists made collages, painted murals, and shared illustrated rendings of pictures of Taylor across social media platforms, flooding positive images of her to the world. These images were not just for optics or aesthetics. Creating art to honor her is a form of protest-showing the world who she was, and how she deserves to be remembered. We made art in her honor, lit candles, and prayed for her and her family. There is still a viscerality to her image that immortalizes her-she should still be here, smiling as she is in the photographs. Being able to take part in this memorializing art speaks to the ways Black feminists are able to capture representation of one another. The pain and sadness is there, but there is also a devastating beauty to them, something that cannot be easily replicated by those that have not experienced exactly how it feels to be positioned in this way in this society. While there is no doubt that some people outside of our sign community could, and many have, produce touching memorials for Taylor, they also run the risk of creating shallow or underthought representations of her and her story.

\section{Race Women}

Threatened by violence, Black feminists are always fully implicated and subsequently haunted by the deaths of Black people. This reminds us that to be haunted is not a choice, but implicit in our very existence. Though we ultimately embrace it, we did not choose to be haunted. Unlike the traditional conception of spectral hauntings marked by fright, we do not fear the ghosts of our brothers and sisters who have been killed at the hands of white supremacist violence. We welcome them into our hearts, we learn about them, we remember them, and we transform the anger and sorrow that we feel into energy that we can use to continue our fight to put an end to the violence that killed them. We also feel a commitment to continue to protect them, by stopping their memories and images from being circulated without thought, or for exploitation that benefits only nonBlack audiences.

This other haunting returns us to Gordon's conceptualization with which we began, and illuminates it moreover. We characterize Black women's relationship to the dead as one haunting, and we posit that the fact of this this haunting produces a second haunting in our relationships with white women. We advance that these two hauntings -one palpable and one ever-grasping for words, one within us and one between us and others-fuel each other. Allies are incapable of experiencing the haunting that we do 
when a Black person is murdered and their story enters the public sphere. This is a critical difference between Black and white people's uptaking of social justice causes, with frightening consequences.

Writing through the events of this year has unexpectedly exposed this reason for the distrust between Black and white women. We have confronted hypocrisy and selfservingness among certain allies, and that has led us to further explore this haunting. White spectators have the option to witness without affect (or not witness at all); whereas Black people are inherently connected to the violence enacted on Black people that we see circulate. White people may experience guilt or empathy, but never the same visceral threat that Black people have no choice but to feel. Our relations to one another are fraught on both sides by Black women's distrust that others could ever invest themselves at the level required for structural change and by white women's position where the fight is always voluntary and never compulsory. This creates an impasse that is always present, impeding the capacity for allyship.

As we ponder the implications of these fraught relations, the constant repetition of "Black Lives Matter" amid questions of unity beg the question, what does it mean to matter? We arrive at an impasse each time an "ally" opts out of acting as though Black lives matter, claiming forgetfulness or "allyship fatigue," and we are reminded that the very nature of allyship negates the idea of equality because it instills the allies with the power to decide whether or not BLM; and allyship itself implies a power structure in which a higher power grants their own capacity to others in order to "help."

In order to move beyond these issues in allyship, we need to begin with reflexivity and adjust actions from there. Begin by asking: when did Black lives start mattering to you? And, what kept you from this before? How will you put this into practice beyond when it is convenient or popular? What comforts and protections are you willing to give up? How will you confront white supremacy in real-time? How will you reckon your own prejudices? When these questions can be answered truthfully, and then be put into action, perhaps then we can think again about the circulation of images, the uptake of intersectionality, and the release of the hauntings that lie in our shadows.

\section{Footnotes}

1. Avery Gordon, Ghostly Matters: Haunting and the Sociological Imagination (Minneapolis: University of Minnesota Press, 1997).

2. Hazel V. Carby, Reconstructing Womanhood: The Emergence of the Afro-American Woman Novelist (Oxford: Oxford University Press, 1987), 5. 
3. By the latter we are describing the discourses of those whom Hazel Carby refers to as "race men," or men who embrace masculinist tendencies in racial politics, effectively excluding women from these conversations. Hazel V. Carby, Race Men (Cambridge: Harvard University Press, 1998). $\_$

4. Carby, Reconstructing Womanhood, 4-5.

5. Frank Wilderson III, Red, White \& Black: Cinema and the Structure of U.S. Antagonisms. (Durham: Duke University Press, 2010), 38.

6. Gordon, Ghostly Matters, $7 . \pm$

7. Jennifer C. Nash, Black Feminism Reimagined: After Intersectionality (Durham: Duke University Press, 2019), 5, 2.

8. Wilderson, Red, White \& Black, 22. See also Saidiya V. Hartman, Scenes of Subjection: Terror, Slavery, and Self-Making in Nineteenth-Century America (New York: Oxford University Press, 1997). $\Xi$

9. Most notably, artists Hannah Black and Parker Bright. $€$

10. Randy Kennedy, "White Artist's Painting of Emmett Till at Whitney Biennial Draws Protests," The New York Times, March 21, 2017, https://www.nytimes.com/2017/03/21/arts/design/painting-of-emmett-till-at-whitney_ biennial-draws-protests.html. $\subseteq$

11. White people have always been being watched, but now the impulse to make a public gesture in response to the BLM is apparent. We attribute it to the movement's place in popular culture and its pervasive presence on social media. $\subseteq$

12. Radley Balko, "The no-knock warrant for Breonna Taylor was illegal," The Washington Post, June 3, 2020, https://www.washingtonpost.com/opinions/2020/06/03/no-knock-warrant-breonnataylor-was-illegall..

13. In June, Louisville's Metro Council members voted unanimously to ban no-knock warrants. $\leftrightarrows$ 